\title{
AC 2007-805: INTRODUCTION TO ENVIRONMENTAL ENGINEERING COURSES AIMED AT RECRUITING AND RETAINING STUDENTS
}

\section{Angela Bielefeldt, University of Colorado at Boulder}

Dr. Bielefeldt is an Associate Professor in the Department of Civil, Environmental, \& Architectural Engineering at the University of Colorado at Boulder (CU). She is the Director for the Environmental Engineering (EVEN) Program which administers the multi-disciplinary B.S. degree in EVEN. She also participates in the Engineering for Developing Communities (EDC) program at $\mathrm{CU}$ at both the undergraduate and graduate levels. 


\title{
Introduction to Environmental Engineering course aimed at Recruiting and Retaining students
}

\begin{abstract}
In Fall 2006, the 1-credit Introduction to Environmental Engineering (EVEN) course was significantly revised. The goals were two-fold: (1) increase the ability of the course to recruit and retain students in the EVEN major; (2) place a greater emphasis on sustainability and global engineering in the course. This is the third significant revision since the course first started in 2000. Over the first 4 years, the course included 7 homework assignments largely geared at basic information to help freshman students be successful and guest lectures by faculty. The second course model (2004 - 2005) included reading of key environmental engineering books (such as Silent Spring, etc), current and former EVEN students as guest speakers, and time for in-class discussion. The third, new, model includes case studies and in-depth assignments similar to higher-level coursework and design in environmental engineering. Student retention data indicates that the second model seems significantly more successful than the first. Student feedback on all three models is compared. The EVEN course is also compared to 1-credit introductory courses offered to students in other majors.
\end{abstract}

\section{Course Models in Freshman Environmental Engineering Course}

At the University of Colorado - Boulder, all of the engineering majors are required to offer a 1credit introductory course to first year students. The specific goals and activities of these courses can vary, but in general they must provide students with basic information on the major and the career options open to students with a degree in that area in order to assist students in understanding the discipline. Students may take more than one of these courses to compare and contrast different majors. Alternatively, students who have not yet selected a specific engineering major (so-called open option students) will take a course that gives an overview of all of the engineering majors available at the University of Colorado. Introductory courses to first-year students are offered at many universities. ${ }^{1,2,3,4}$ Sometimes a full 3-credits is allocated to the course and it is project-based. At the University of Colorado, students have an opportunity to take a first-year 3-credit projects course ${ }^{5,6}$, although this course isn't required across all majors. In addition, students are often enrolled in project sections that are not at all related to the major they are interested in, so keeping the 1-credit courses for major-specific information is important. Regardless of the form, first-year courses are generally found to be critical opportunities to engage students and help retain them in engineering.

In Fall 2006, the 1-credit Introduction to Environmental Engineering (EVEN) course was significantly revised. The goals were two-fold: (1) increase the ability of the course to recruit and retain students in the EVEN major; (2) place a greater emphasis on sustainability and global engineering in the course. In fact, it was hypothesized that the emphasis on sustainability and global engineering could help achieve the recruiting and retention goal, particularly for female and minority students. Previous research has indicated that these topics help attract women to engineering. ${ }^{7}$ In addition, Seymour found that: "In the process of developing and clarifying their career goals, however, women expressed more altruism than men and were more likely to switch 
to career paths that reflected humanitarian goals or offered more satisfying work." 8 The students who enroll in the course vary widely in their year in college, major, etc. Relevant demographics over the 7 offerings of the course are summarized in Table 1; an average of $51 \%$ of the enrolled students (64 students) were EVEN majors at the time. Non-EVEN majors include open option engineering, undeclared majors in the College of Arts and Sciences, etc. Some of those students are considering EVEN as a potential major (usually freshman and sophomores), while others just want to learn about EVEN without a significant likelihood that they will change their major.

Table 1. Demographics of students in first-year Environmental Engineering course

\begin{tabular}{|c|c|c|c|c|c|c|c|}
\hline Year & $\begin{array}{c}\text { course } \\
\text { model }\end{array}$ & $\begin{array}{c}\text { Total } \\
\text { enrollment }\end{array}$ & $\begin{array}{c}\% \\
\text { female }\end{array}$ & $\begin{array}{c}\% \\
\text { minority }\end{array}$ & $\begin{array}{c}\% \\
\text { EVEN }\end{array}$ & $\begin{array}{c}\% \\
\text { Freshmen }\end{array}$ & $\begin{array}{c}\text { Avg FCQ } \\
\text { course rating }\end{array}$ \\
\hline 2000 & frosh ex & 13 & 55 & 0 & 77 & 62 & 2.3 \\
\hline 2001 & frosh ex & 16 & 44 & 13 & 56 & 75 & 2.7 \\
\hline 2002 & frosh ex & 12 & 58 & 25 & 50 & 25 & 3.0 \\
\hline 2003 & frosh ex & 14 & 21 & 29 & 36 & 86 & 3.0 \\
\hline 2004 & readings & 23 & 48 & 22 & 48 & 83 & 3.3 \\
\hline 2005 & readings & 18 & 22 & 17 & 50 & 56 & 3.3 \\
\hline 2006 & projects & 29 & 48 & 28 & 48 & 55 & NA \\
\hline 7 yrs & & 125 & 42 & 20 & 51 & 64 & \\
\hline
\end{tabular}

Over time, the activities and emphasis of the course has changed, with highlights shown in Table 2. In the initial offerings from 2000-2003 ("frosh ex"perience, in Table 1), the course had two stated objectives: acquaint students with the field of EVEN and facilitate success in studying engineering. The first objective was achieved largely by having faculty with different research emphasis come and give lectures (5 lectures), 1 practicing engineer as a guest speaker, and a tour of a drinking water treatment facility. There were also a number of lectures and assignments to help freshman students be successful in college (study strategies, time management, skills evaluation, etc.; 7 lectures).

In the second course model (readings, in Table 1), the first objective was modified to explicitly also introduce students to EVEN as an academic major. Two additional objectives were specified: instill a sense of ethics and commitment to service, and develop writing skills. Writing skills were developed through a series of 4 writing assignments, each of which went through mandatory revision process based on instructor and an "Online Writing Lab" critique. Guest speakers (about 6) were practicing EVENs (many former students in the program), 1 current upper level student. Students read 2 to 3 significant books related to EVEN (such as Silent Spring), which were the subject of in-class discussions and writing assignments. Finally, ethics was covered as a significant topic. In 2004, students wrote essays ( half page) on "Why Environmental Engineering" at the beginning of the semester. These typically indicated a fairly poor understanding of EVEN and just a general curiosity due to "environmental" interest and ability and enjoyment of math and science. Based on the average student ratings of the course in the Faculty Course Questionnaires (FCQs) administered by the University at the end of the semester (Table 1), the second course model was more favorably received than the first. 
In the third course model, the main course objectives related to familiarizing students with the field of EVEN, what environmental engineers do on the job, and providing an ethical framework. However, an unstated goal is to attract students to the EVEN major and retain students already enrolled, particularly of groups under-represented in engineering. It was hypothesized that emphasis on sustainability and global impacts of environmental engineering could help achieve these goals. The course activities included:

- an initial homework with an overview of EVEN skills, employment, etc

- a case study of sustainable and appropriate wastewater treatment (3 weeks)

- a module on ethics, including an engineer involved in global development work as a moral exemplar (Fred Cuny)

- students plotting a course plan to graduate with an EVEN degree

- a 4-week team project on solid waste that included global warming impacts from landfills, recycling, and alternative energy aspects

- practicing engineers (3) as guest speakers

- a final reflective essay on EVEN

Table 2. Comparison of activities in first-year introductory EVEN course

\begin{tabular}{|l|c|c|c|}
\hline Course activity/topic & $\begin{array}{c}2000-2003: \\
\text { Frosh ex }\end{array}$ & 2004-2005: Readings & 2006: Projects \\
\hline $\begin{array}{l}\text { Course plan / EVEN } \\
\text { curriculum }\end{array}$ & $\begin{array}{c}1 \text { full lecture; } \\
\text { partial lectures }\end{array}$ & 3 lectures & 1 lecture; 1 homework \\
\hline Ethics & $\begin{array}{c}1 \text { lecture, } \\
\text { homework }\end{array}$ & $\begin{array}{c}\text { 1 lecture, 1 discussion, } \\
1 \text { homework }\end{array}$ & $\begin{array}{c}1 \text { lecture, } 1 \text { discussion, } \\
1 \text { homework }\end{array}$ \\
\hline $\begin{array}{l}\text { Practicing EVENs as } \\
\text { guest speakers }\end{array}$ & 1 & 6 & 3 \\
\hline Unique aspect & $\begin{array}{c}\text { frosh eng skills; } \\
\text { research/faculty } \\
\text { lectures }\end{array}$ & $\begin{array}{c}\text { read 2-3 major EVEN } \\
\text { books; in-class } \\
\text { discussions }\end{array}$ & $\begin{array}{c}1 \text { case study; } \\
1 \text { team project }\end{array}$ \\
\hline
\end{tabular}

A key aspect of engineering curricula is that the courses contribute to achieving the ABET Criterion 3 (a) - (k) outcomes ${ }^{9}$. In 2000 to 2005 the course instructors determined how the course materials mapped to the ABET outcomes criteria, with results shown in Table 3. For 2006, the individual course activities have been mapped to the ABET criteria. In 2006, students were asked to evaluate if the team-based solid waste project contributed to their knowledge in specific ABET-criteria areas (not at all $=0$, a little $=1$, moderate $=2$, significant $=3$ ). These surveys were filled out on the day the written assignment was due; 28 surveys were returned. Results are summarized in Table 3. The total points awarded by the students indicated that the most significant benefit of the project in terms of student skills and abilities were: communicate effectively, design a process to meet needs within realistic constraints, understanding the impacts of engineering solutions, and function on multi-disciplinary teams. A broader range of outcomes appear to result from the case study and team project approach compared to the other course strategies. 
Table 3. Mapping of Course Models to ABET Criteria

\begin{tabular}{|c|c|c|c|c|c|c|}
\hline \multirow[t]{2}{*}{ ABET } & \multirow{2}{*}{$\begin{array}{l}2000- \\
2003\end{array}$} & \multirow{2}{*}{$\begin{array}{l}2004- \\
2005\end{array}$} & \multicolumn{3}{|c|}{2006 project* } & \multirow[t]{2}{*}{2006} \\
\hline & & & & 2 & 3 & \\
\hline $\begin{array}{l}\text { a) apply knowledge of math, science, } \\
\text { engrg }\end{array}$ & & & & 13 & 3 & project \\
\hline $\begin{array}{l}\text { c) design process to meet needs } \\
\text { within realistic constraints }\end{array}$ & & & 1 & 14 & 11 & $\begin{array}{l}\text { case study } \\
\text { illustrates design } \\
\text { criteria/constraints }\end{array}$ \\
\hline d) function on teams & & & 3 & 16 & 8 & 1 team project \\
\hline $\begin{array}{l}\text { e) identify, formulate, solve engrg } \\
\text { problems }\end{array}$ & & & 5 & 13 & 8 & case sty/LF project \\
\hline $\begin{array}{l}\text { f) understand professional \& ethical } \\
\text { responsibility }\end{array}$ & $\mathrm{x}$ & $\mathrm{x}$ & 9 & 6 & 9 & $\begin{array}{l}\text { lecture, homework, } \\
\text { discussion }\end{array}$ \\
\hline g) ability to communicate effectively & $\mathrm{x}$ & $\mathrm{xx}$ & 5 & 7 & 15 & $\begin{array}{l}\text { written reports; oral } \\
\text { presentation }\end{array}$ \\
\hline $\begin{array}{l}\text { h) understand impact of engineering } \\
\text { solutions in global and societal } \\
\text { context }\end{array}$ & $\mathrm{x}$ & $\mathrm{xx}$ & 4 & 16 & 8 & $\begin{array}{l}\text { case study, team } \\
\text { project, ethics case }\end{array}$ \\
\hline i) engage in life-long learning & & $\mathrm{x}$ & 20 & 3 & 5 & \\
\hline j) knowledge of contemporary issues & & $\mathrm{x}$ & 5 & 18 & 5 & $\mathrm{X}$ \\
\hline k) use modern engineering tools & & & 7 & & 5 & $\begin{array}{l}\text { EPA LandGEM } \\
\text { model for project }\end{array}$ \\
\hline
\end{tabular}

* The number of students ranking the contribution of the team project to their abilities in each area are shown: $1=$ a little, $2=$ moderate, $3=$ significant

In the end-of-semester reflective essays in 2006, 14 students referred to the landfill project and guest lectures as being influential in their opinions of environmental engineering, with an additional 11 references to the case study and 10 statements about the ethics assignment. FCQ data are not yet available.

\section{Comparison of Retention Data}

As of September 2006, only 38\% of the students who had taken EVEN1000 (47 students) were still EVEN majors or graduated with an EVEN degree. This data indicates some attrition rate of students. It is still somewhat early to correlate course format evolution since 2000 to retention in EVEN. The best way to compare retention with short-term data is to look at retention after 3 and 5 semesters. These retention values were calculated based on students who were initially declared majors upon entering the first-year course (students not initially declared majors would be considered attracted to the major). Retention rates have been calculated for EVEN, with results shown in Table 4. For comparison, retention from the first-year Chemical (CHEN) and Civil (CVEN) Engineering courses and College-wide ${ }^{6,10}$ are also shown. From $2000-2003$, third semester student retention from EVEN are significantly lower than CHEN, CVEN, and College-wide. These differences are smaller at the $5^{\text {th }}$ semester. These differences may be due to a combination of factors rather than course structure alone, including instructor, certainty of major selection, etc. Each course model has been taught by a different instructor. Also, many EVEN students want to save the environment, but feel that they can also accomplish this goal by 
majoring in Environmental Studies or a related science. It is also important to realize that the EVEN retention percentages are based on very low initial numbers of students, so small year-toyear fluctuations could be inherent variability. In Fall 2003, for example, only 1 student remained of initial 5 EVEN students in the class after 3 and 5 semesters; this student will likely be graduating in May 2007. The College values are also expected to be higher than an individual major because they include all students retained in Engineering, irrespective of major, while the EVEN, CHEN, and CVEN numbers do not count students if they switched to a different engineering major.

Table 4. Retention of students from first-year EVEN and CVEN courses and College-Wide

\begin{tabular}{|c|c|c|c|c|c|c|c|c|c|}
\hline $\begin{array}{c}\text { Year } \\
\text { start }\end{array}$ & \#EVEN & EVEN & CHEN & CVEN & College & EVEN & CHEN & CVEN & College \\
\hline $\begin{array}{c}1994 \\
\text { to } \\
1999\end{array}$ & NA & NA & ND & ND & $78-84$ & NA & ND & ND & $62-70$ \\
\hline 2000 & 10 & 60 & 75 & 83 & 81 & 50 & 64 & 67 & 64 \\
\hline 2001 & 9 & 56 & 66 & 82 & 81 & 44 & 63 & 64 & 67 \\
\hline 2002 & 6 & 67 & 73 & 76 & 78 & 67 & 64 & 76 & 64 \\
\hline 2003 & 5 & 20 & 71 & 67 & 81 & 20 & 74 & 50 & 62 \\
\hline 2004 & 11 & 73 & 68 & 97 & 80 & 55 & 68 & 90 & ND \\
\hline 2005 & 9 & 78 & 69 & ND & ND & NA & NA & NA & NA \\
\hline 2006 & 14 & NA & NA & NA & NA & NA & NA & NA & NA \\
\hline
\end{tabular}

$\mathrm{ND}=$ not determined; $\mathrm{NA}=$ not available.

The preliminary data indicates a higher retention from the 2004-2005 EVEN course model compared to the 2000-2003 model. This correlates to higher student ratings of the course and instructor in the end-of-semester faculty:course questionnaires (FCQs). This appears to indicate that the 7 homework assignments largely geared at basic information to help freshman students be successful and guest lectures by faculty was somehow less inspiring or motivational to stay in EVEN than the reading of key environmental engineering books, current and former EVEN students as guest speakers, and time for in-class discussion. The second model may have allowed the students to form a better sense of community than the first, which could also help retention. Also, a few non-EVEN students were recruited into EVEN via first year course: in course model 1 from 2000 through 2003: 1, 0, 2, and 0 each year (0-33\% recruiting); in course model 2 from 2004-2005: 2 and 3 students each year (17-33\% recruited).

It is still too early for student FCQ feedback and retention data from the third course model of case studies and in-depth assignments similar to higher-level coursework and design in environmental engineering. However, this model of problem- and team-based learning has used in the CVEN first year course since 2000, with sustainability and global engineering emphasis in 2003-2004. The retention data appear higher than the EVEN retention, while FCQs (Table 5) are not significantly different. Some indications of retention and recruiting to EVEN from the third course model can be gathered from the end-of-semester reflection essays submitted by the students. Of the 14 students who were EVEN majors at the start of the semester, 12 still plan to stay in EVEN and 2 plan to switch out of engineering entirely (both due to stated dislike of their computing and calculus courses). Four additional students stated that they would like to change 
their major to EVEN (from current majors both inside and outside of the College of Engineering) and another 3 students indicated that they might select EVEN but were still undecided. Most indicated that the course and subject matter of EVEN were interesting, but for various reasons planned to stick with their current majors or go in a related direction (biology, math majors). It was interesting to note how many of the students indicated that they didn't really know what EVEN was at the beginning of the semester; even those who had selected EVEN as their major. This indicates that greater public education and outreach to high school counselors may be in order for our profession.

College-wide from 1994 through 2004, retention rates at the $3^{\text {rd }}, 5^{\text {th }}, 7^{\text {th }}$ semester and graduation after 6 years are 81, 66, 58, and 52\%, respectively. Note that this allows for students to change majors within the College of Engineering, not necessarily being retained within their initial major. For women these rates are similar to slightly higher (56\% graduation) and for underrepresented minorities these rates are slightly lower (44\% graduation) ${ }^{10}$. Because the EVEN student numbers are so low, comparisons of female and minority student retention have not been made. For the first year EVEN course, the graduation rates of EVEN students out of EVEN have ranged from 40-50\% after 5 yrs; these numbers are somewhat lower than College, but do not include students that may have graduated from a different Engineering major. Comparable numbers of how many engineering students start and finish within the same major are not readily available.

\section{Course Models in Freshman Courses College-Wide}

The EVEN course can be compared to other 1-credit introductory courses offered for Civil (CVEN), Chemical (CHEN), Mechanical (MCEN), and undeclared engineering (GEEN) majors, as shown in Table 5. For undeclared majors, the course format is similar to model (1). For CVEN majors the course format is similar to model (3). Enrollment in the first-year EVEN course (average 18/yr) is significantly lower than that in the Introductory courses in the other programs which range from 48 to 118 students. The average FCQ ratings for all courses from $2000-2005$ are nearly identical.

Table 5. Relevant Demographics in Freshman Introductory Courses (2000-2006)

\begin{tabular}{|l|c|c|c|c|c|c|c|c|}
\hline Course & $\begin{array}{c}\text { Enrollment } \\
\text { per year }\end{array}$ & $\begin{array}{c}\text { ave } \\
\text { FCQ } \\
\text { course } \\
\text { rating }\end{array}$ & $\begin{array}{c}\% \\
\text { female }\end{array}$ & $\begin{array}{c}\% \\
\text { minority }\end{array}$ & $\begin{array}{c}\% \text { in } \\
\text { major }\end{array}$ & $\begin{array}{c}\% \\
\text { Freshmen }\end{array}$ & $\begin{array}{c}\% 5^{\text {th }} \\
\text { semester } \\
\text { retention* }\end{array}$ & $\begin{array}{c}\% 5^{\text {th }} \\
\text { semester } \\
\text { recruit* }\end{array}$ \\
\hline EVEN & $12-29$ & 2.9 & $21-55$ & $0-28$ & $36-77$ & $25-86$ & $20-67$ & $0-33$ \\
\hline CVEN & $31-64$ & 2.7 & $10-30$ & $7-20$ & $54-76$ & $59-90$ & $50-90$ & $10-31$ \\
\hline CHEN & $46-67$ & 2.8 & $29-49$ & $9-30$ & $51-69$ & $72-84$ & $63-74$ & $25-43$ \\
\hline MCEN & $94-129$ & 2.8 & $6-12$ & $12-18$ & $45-85$ & $82-89$ & $57-66$ & $51-60$ \\
\hline GEEN & $96-137$ & 2.6 & $13-25$ & $4-15$ & $90-97$ & $81-98$ & NA & NA \\
\hline
\end{tabular}

* From courses taught in 2000 to 2004 . NA = not applicable

Retention was computed as the number of students that began the semester in the first-year course as declared in the major that were still in the major in their $5^{\text {th }}$ semester. The differences in the retention of students from the various majors should not be exclusively attributed to 
differences in first-year course structure and content. For example, a significant confounding factor is that some majors require and teach sections of the 3-credit freshman projects course while others do not. For example, EVEN requires the freshman projects course while CVEN does not. Data has already shown that there is better retention of students taking the freshman projects course compared to those students that do not take the projects course ${ }^{6}$. Recruitment was computed as the percentage of students enrolled in the first-year course who were not the stated major, but 5 semesters later were declared in the major of interest.

In the introductory Chemical Engineering (CHEN) course, the best part is that the students get to meet all of the CHEN faculty members and briefly hear about their research areas (15 min per class period). The course is 75-min long instead of 50-minutes, with a typical period broken into 2 to 3 topics, rather than a single lecture for the entire period. Students go on a field trip, compete in the E-days egg drop contest as teams, and complete journals and personal papers. There is also a good range of panels to inform students about various options in the curriculum, extracurricular opportunities, and post-graduation career paths.

The Mechanical Engineering (MCEN) course model is unique, with both a lecture (1 hr/wk) and a lab $\sim$ hrs/wk (as of Fall 2006). The course introduces facets of mechanical engineering including the history of the profession, mechanical engineering curriculum, industries in which mechanical engineers practice, and expectations and tools for academic success. Students participate in hands-on experiences, visit industry, make oral presentations, meet faculty and practicing professionals, and develop goal statements. The most distinctive outcome of the course is the significantly higher recruiting of majors compared to the other courses. However, MCEN also teaches the most popular sections of the 3-credit Engineering Project course, so the recruiting may not be due to MCEN 1000 alone.

Overall, it appears that first-year courses that include more "rich" experiences for students rather than merely a series of lectures or guest speakers is more effective at retaining and recruiting students to the major. These experiences may be projects, in-class discussions, etc. These detailed assignments allow students to obtain a more accurate view of the complexity of problem-solving in a given discipline, and can indicate specific challenges in a more meaningful way than the students can learn on their own by reading descriptions of the professional on the web or in other resources. Further investigations are needed to verify this assertion.

\section{Summary and Conclusions}

In summary, 1-credit introductory first-year courses for engineering students are opportunities to inform students about the profession. Many different models are possible. However, preliminary information from the University of Colorado - Boulder indicates that an EVEN course that relied heavily on general "exercises" and information geared to help students be successful in College and faculty lectures was less helpful for student retention and recruiting than a model with many guest lectures by practicing engineers and current/former students and significant reading, writing, and discussion. It is still too early to determine if the new problembased model with sustainability related cases will be successful. Future tracking of these students will help answer this question. However, the success of the 3-credit project course and other literature indicates that this could be a successful approach. 


\section{Bibliography}

1. Hagenberger, M., B. Engerer, and D. Tougaw. 2006. Revision of a first-semester course to focus on fundamentals of engineering. ASEE. Paper 2006-1360.

2. Hampe, M. and S. Wolf. 2006. How to provide first-year-students with a really good start into their study program. ASEE. Paper 2006-1284.

3. Elzey, Dana. 2006. Teaching Intro to Engineering in Context - UVA Engineering's New Cornerstone. ASEE. Paper 2006-1574.

4. Patterson, Kurt. 2006. Critical connections: a first-semester course in environmental engineering. ASEE. Paper 2006-1102.

5. Carlson, L.E., J.F. Sullivan, A.J. Bedard, D.M. Etter, and A.R. Pleszkun. 1995. First Year Engineering Projects: An Interdisciplinary, Hands-On Introduction to Engineering. ASEE. Session 2653.

6. Knight, D.W., L.E. Carlson, and J.F. Sullivan. 2003. Staying in Engineering: Impact of a Hands-On, TeamBased, First-Year Projects Course on Student Retention. ASEE. Session 3553

7. Bielefeldt, A.R. 2006. Attracting Women to Engineering that Serves Developing Communities. ASEE. Paper 2006-1221.

8. Seymour, Elaine. 1999. The Role of Socialization in Shaping the Career-Related Choices of Undergraduate Women in Science, Mathematics, and Engineering Majors. Annals of the New York Academy of Sciences. 869: 118-126.

9. ABET. 2004. Criteria for Accrediting Engineering Programs. www.abet.org

10. DIVERSITY PLAN. College of Engineering and Applied Science. University of Colorado at Boulder. Approved 11 September 2006 by the Administrative Council. 